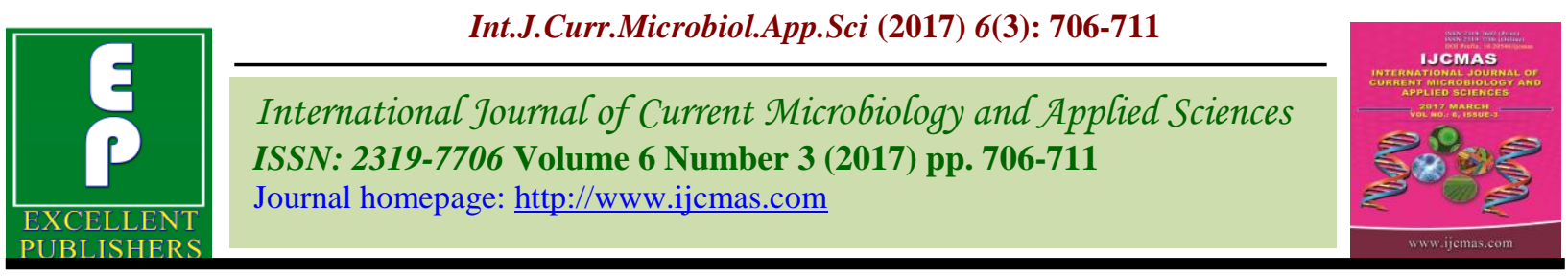

Original Research Article

https://doi.org/10.20546/ijcmas.2017.603.081

\title{
Mobile Phones in Healthcare Setting: Potential Threat in Infection Control
}

\author{
P.C. Ganapathy Shakthivel, G. Velvzhi*, G. Sucilathangam and C. Revathy \\ Department of Microbiology, Tirunelveli Medical College, Tirunelveli - 627 011, \\ Tamil Nadu, India \\ *Corresponding author
}

\section{A B S T R A C T}

\begin{tabular}{|l|}
\hline Ke y w or d s \\
Mobile phones, \\
$\begin{array}{l}\text { Healthcare workers, } \\
\text { Micrococci, } \\
\text { E.coli, MRSA. }\end{array}$ \\
\hline Article Info \\
\hline $\begin{array}{l}\text { Accepted: } \\
\text { 15 February } 2017 \\
\text { Available Online: } \\
\text { 10 March } 2017\end{array}$ \\
\hline \hline
\end{tabular}

Mobile phones are used in close contact with the body and, as for most non-medical electronic equipment, there are no cleaning guidelines available that meet hospital standards, and the hygiene risk involved in using mobile phones has not yet been determined. The present study was undertaken to investigate bacterial contamination of the mobile phones of the healthcare workers employed in a tertiary care hospital and also to assess the usefulness of simple cleaning with $70 \%$ isopropyl alcohol for their decontamination. A total of 50 health care workers of a tertiary hospital were selected randomly. Growth of bacteria was identified by studying colony morphology, gram staining and by standard biochemical tests. Antibiotic sensitivity testing of isolates was done by modified Kirby-Bauer method. Mobile phones of the doctors mostly harboured commensal bacteria [Coagulase Negative Staphylococci 3 (30\%), Micrococci 5(50\%), aerobic bacterial spores 1(10\%)] and the mobile phones of the hospital workers mostly harboured pathogenic bacteria Micrococci 3(30\%), E.coli 2(20\%), Klebsiella oxytoca 2 (20\%) and aerobic bacterial spores 1(10\%).The isolated Staphylococcus aureus isolates were resistant to Cefoxitin (MRSA). The two Klebsiella oxytoca isolates were found to be multi drug resistant. Mobile phone decontamination efficacy of $70 \%$ isopropyl alcohol in our study was about $86.6 \%$. To prevent the potential spread of infections through mobile phones, training of the health care personnel about strict infection control practices, hand hygiene, environmental disinfection and routine decontamination of mobile phones with alcohol should be advocated to prevent the spread of infection in the hospital settings.

\section{Introduction}

Hospital acquired infections are a problem in both developed and developing countries despite overall progress. It significantly increases the patient's length of stay in hospital resulting in higher hospital costs. Source of infection may be exogenous such as from the air, medical equipment, hands of surgeons and other staff or endogenous such as the skin flora in the operative site, or rarely from blood used in the surgery (Ducel et $a l ., 2002)$. The hands of healthcare workers play an important role in transmission of Nosocomial pathogens.

With recent advances in the source of information, mobile phone use has become indispensible in hospitals (Gurang et al., 2008). The use of cell phones often occurs in hospital halls, laboratories, and/or intensive care units when dealing with severe illnesses. Mobile phones may transmit more than just information in today's busy hospitals. They 
may also be involved in the transmission of infections in the healthcare systems (Rawia et al., 2012; Kabir et al., 2009).

Mobile phones are used in close contact with the body and, as for most non-medical electronic equipment, there are no cleaning guidelines available that meet hospital standards, and the hygiene risk involved in using mobile phones has not yet been determined. To address this issue, this study was undertaken to investigate bacterial contamination of the mobile phones of the healthcare workers employed in a tertiary care hospital and also to assess the usefulness of simple cleaning with $70 \%$ isopropyl alcohol for their decontamination.

\section{Materials and Methods}

\section{Study Population}

A total of 50 health care workers of a tertiary hospital were selected randomly. After obtaining their consent, they were asked to answer the questionnaire - their profession, whether they use their phones between patients, usage of phones with gloved hands and whether routine cleaning of phones had been done were recorded. The study was undertaken after obtaining approval from institutional ethical committee. Mobile phones of doctors, nurses, laboratory technicians, nursing assistants \& hospital workers were included in the study over a period of 2 months, from 1st July 2015to 31stAugust 2015.

\section{Sample collection and processing}

From each mobile phone two swabs were collected with help of sterile cotton swabs. The mobile phone was first held in the sterile gloved hand and the samples were collected by using sterile swabs moistened with normal saline rotating and streaking over the screen, keypad, sides and external cover surface of the mobile phone. (Before decontamination swab).The mobile phone was then thoroughly cleaned with $70 \%$ isopropyl alcohol swab for 5 to 7 minutes and another swab was collected (After decontamination swab)

\section{Laboratory procedure}

The collected samples were immediately transferred to microbiology laboratory and inoculated on Blood agar, Nutrient agar and MacConkey agar. The plates were incubated at $37^{\circ} \mathrm{C}$ for 24 hours and observed for the growth. Growth of bacteria was identified by studying colony morphology, gram staining and by standard biochemical tests. Antibiotic sensitivity testing of isolates was done by modified Kirby-Bauer method in accordance to Clinical and Laboratory Standards Institute (CLSI) guidelines.

\section{Results and Discussion}

This study revealed that out of a total of 50 mobile phones screened for microbial colonization, 45(90\%) were found to be positive comprising of various pathogenic bacteria and commensal bacteria.

The distribution of commensal bacteria were Micrococci 24 (48\%), Coagulase Negative Staphylococci 6 (12\%), and aerobic bacterial spores $9(18 \%)$ while the pathogenic bacteria isolated were Escherichia coli 2 (4\%), Staphylococcus aureus $2(4 \%)$ and Klebsiella oxytoca 2 (4\%).Category wise distribution of bacterial isolates were shown in Table 1 .

The antibiotic sensitivity pattern of the isolates revealed that CONS were sensitive to Ciprofloxacin, Vancomycin and Amikacin. Both isolated Staphylococcus aureus isolates were resistant to Cefoxitin (MRSA). Klebsiella oxytoca isolates were sensitive to Ciprofloxacin, Amikacin and Gentamicin and 
resistant to Ceftazidime, Ceftazidime with Clavulanic acid and Septran. Escherichia coli were sensitive to all the tested antibiotics.

The questionnaire analysis showed almost all cadres of healthcare workers use mobile phones in the hospital. Among them, about 20 (40\%) use mobile phones while attending to the patients, only $5(10 \%)$ of them used to wipe their mobile phones with disinfectants regularly. About 6(12\%) healthcare workers had the habit of washing their hands after using their mobile phones. About 25(50\%) healthcare workers under the study had the habit of washing their hands before attending to the patients. Nearly $26(52 \%)$ healthcare workers agreed that mobile phones may act as vector for spread of nosocomial infections. About 42(84\%) healthcare workers shared their mobile phones with their colleagues. About 44(88\%) healthcare workers shared their mobile phones at home. This is depicted in Table-2.

The study also analysed the use of decontamination of mobile phones with $70 \%$ isopropyl alcohol. About 45(90\%) mobile phones showed positive bacterial growth before decontamination. After decontamination with $70 \%$ isopropyl alcohol only $6(12 \%)$ mobile phones showed positive bacterial growth, thus the efficacy of $70 \%$ isopropyl alcohol in our study was about 86.6\%.This is depicted in Table 3.

Mobile phones have become an essential commodity in man's day-to-day life. In India, mobile phones account for more than $88 \%$ of all telecom users. It is carried by the doctors during visits to the hospital and is extensively used within the hospital premises including areas like Operation theatres and Intensive care units. If proper infection control practices especially hand hygiene are not followed these device can serve as a reservoir of infection.
The present study showed that about $90 \%$ of the mobile phones screened were contaminated with pathogenic and commensal bacteria which is similar to the study conducted by Karabay et al., (2007) who showed the rate of $90.98 \%$ mobile contamination. The studies conducted by Ulger et al., (2009) Tambekar et al., (2008) showed higher rates of contamination $(94.5 \%$, 95\%). In contrary, studies conducted by Killic et al., (2009) and Datta et al., (2009) found contamination of mobile phones to be $61.3 \%$ and $72 \%$ respectively which are less than the rate of mobile phone contamination in the current study.

The incidence of gram positive organism mainly Micrococci (48\%) is high as it is commonly found in the environment and it is a transient flora in the normally healthy skin The other organisms that were isolated includes CONS (12\%),Staphylococcus aureus (4\%), Klebsiella oxytoca (4\%), and Escherichia coli (4\%). These organisms may perhaps found their way through the skin and hands because mobile phones are seldom cleaned and often touched during or after examination of patients and handling of specimens, without proper hand wash.

The mobile phones of majority of doctors and staff nurse harboured Micrococci followed by aerobic bacterial spores and Staphylococcus aureus. The mobile phones of lab technicians and nursing assistants mainly showed growth of commensals like Micrococci, CONS and aerobic bacterial spores. The mobile phones of hospital workers harboured the gram negative bacteria Eschericia coli, Klebsiella oxytoca in addition to Micrococci and aerobic bacterial spores. Similar to this result, other studies have also demonstrated the presence of these bacteria as contaminants of healthcare workers' mobile phones (Sepehri et al., 2009). On the other hand, certain studies had also reported organisms like 
Pseudomonas species, Neisseria species, and Acinetobacter species which were not isolated in this study (Chawla et al., 2009; Gunasekara et al., 2009). Even though the isolated strains of Staphylococcus aureus were minimal in number their antibiotic sensitivity pattern showed resistance to Cefoxitin.

Table.1 Category wise distribution of bacterial isolates

\begin{tabular}{|l|l|l|l|l|l|l|}
\hline $\begin{array}{l}\text { Health Care } \\
\text { Workers }\end{array}$ & $\begin{array}{l}\text { CONS } \\
(\%)\end{array}$ & $\begin{array}{l}\text { Micrococci } \\
(\%)\end{array}$ & $\begin{array}{l}\text { Aerobic } \\
\text { bacterial } \\
\text { spores(\%) }\end{array}$ & $\begin{array}{l}\text { Staphylococcus } \\
\text { aureus } \\
(\%)\end{array}$ & $\begin{array}{l}\text { Escherichia } \\
\text { coli } \\
(\%)\end{array}$ & $\begin{array}{l}\text { Klebsiella } \\
\text { oxytoca } \\
(\%)\end{array}$ \\
\hline Doctors $(\mathrm{n}=10)$ & $3(30)$ & $5(50)$ & $1(10)$ & $1(10)$ & 0 & 0 \\
\hline Staff Nurse(n=10) & 0 & $7(70)$ & $1(10)$ & $1(10)$ & 0 & 0 \\
\hline $\begin{array}{l}\text { Lab } \\
\text { Technicians(n=10) }\end{array}$ & $2(20)$ & $4(40)$ & $3(30)$ & 0 & 0 & 0 \\
\hline $\begin{array}{l}\text { Nursing Assistants } \\
(\mathrm{n}=10)\end{array}$ & $1(10)$ & $5(50)$ & $3(30)$ & 0 & 0 & 0 \\
\hline $\begin{array}{l}\text { Hospital } \\
\text { Workers(n=10) }\end{array}$ & 0 & $3(30)$ & $1(10)$ & 0 & $2(20)$ & $2(20)$ \\
\hline
\end{tabular}

Table.2 Participants' response for questions related to the use of Mobile phones

\begin{tabular}{|l|l|l|}
\hline \multirow{2}{*}{ Habits } & Response of Health care workers $(\mathbf{N}=\mathbf{5 0}) \%$ \\
\cline { 2 - 3 } & Yes & No \\
\hline $\begin{array}{l}\text { Using cell phones in the } \\
\text { hospital } \\
(\%)\end{array}$ & $50(100)$ & 0 \\
\hline $\begin{array}{l}\text { Using cell phones while } \\
\text { attending the patients(\%) }\end{array}$ & $20(40)$ & $30(60)$ \\
\hline $\begin{array}{l}\text { Using disinfectants to wipe } \\
\text { their mobile phones(\%) }\end{array}$ & $5(10)$ & $45(90)$ \\
\hline $\begin{array}{l}\text { Washing hands after using } \\
\text { their phones(\%) }\end{array}$ & $6(12)$ & $44(88)$ \\
\hline $\begin{array}{l}\text { Washing hands before } \\
\text { attending patients(\%) }\end{array}$ & $25(50)$ & $25(50)$ \\
\hline $\begin{array}{l}\text { Awareness about spreading } \\
\text { infections through } \\
\text { phones(\%) }\end{array}$ & $26(52)$ & $24(48)$ \\
\hline $\begin{array}{l}\text { Sharing cell phones with }- \\
\text { colleagues(\%) }\end{array}$ & $42(84)$ & $6(16)$ \\
\hline $\begin{array}{l}\text { Sharing cell phones at home } \\
\text { (\%) }\end{array}$ & $44(88)$ & $6(12)$ \\
\hline
\end{tabular}


Table.3 Percentage of bacterial growth before and after decontamination of Mobile phones with $70 \%$ isopropyl alcohol

\begin{tabular}{|l|l|l|l|}
\hline Cell phones(n=50) & Growth positive & Growth negative & Total \\
\hline $\begin{array}{l}\text { Before } \\
\text { decontamination }\end{array}$ & $45(90 \%)$ & $5(10 \%)$ & $50(100 \%)$ \\
\hline After decontamination & $6(12 \%)$ & $44(88 \%)$ & $50(100 \%)$ \\
\hline
\end{tabular}

Similarly the Klebsiella oxytoca strains that were isolated showed resistance to Ceftazidime, Ceftazidime with Clavulanic acid and Septran antibiotics. These Methicillin resistant Staphylococcus aureus (MRSA) and multidrug resistant Klebsiella oxytoca are potentially dangerous organisms in the spread of nosocomial infections.

Decontamination of the mobile phones with $70 \%$ isopropyl alcohol proved to be effective. About 45 mobile phones (90\%) showed positive bacterial growth prior to decontamination. About 39 mobile phones (78\%) showed zero bacterial growth after decontamination with $70 \%$ isopropyl alcohol. The remaining 6 mobile phones (12\%) showed decreased bacterial growth after decontamination. Thus the efficacy of $70 \%$ isopropyl alcohol in our study was about $86.6 \%$. This result was higher than a study conducted elsewhere in the world which showed an efficacy of $47.8 \%$ (Muktar et al., 2014). In contrast, a study conducted by Arora et al., (Arora et al., 2009) showed a higher decontamination efficacy of about $98 \%$ with $70 \%$ isopropyl alcohol.

Only $10 \%$ of the healthcare workers had the habit of wiping their mobile phones with disinfectants regularly. If decontamination of mobile phones with $70 \%$ isopropyl alcohol is made as a regular practice among healthcare workers, the spread of nosocomial infections through mobile phones can be significantly reduced.
To conclude our study reveals that mobile phones of HCW's may get contaminated with pathogenic bacteria which can cause hospital infections and may serve as reservoirs and vehicle of transmission of infection to both hospital and community. To prevent the potential spread of infections through mobile phones, training of the health care personnel about strict infection control practices, hand hygiene, environmental disinfection and routine decontamination of mobile phones with alcohol should be advocated to prevent the spread of infection in the hospital settings.

\section{References}

Arora, U., Devi, P., Chadha, A., Malhotra, S. 2009. Cellphones a modern stay house for bacterial pathogens. JK Sci., 11(3): 127-129.

Chawla, K., Mukhopadhayay, C., Gurung, B., Bhate, P., Bairy, I. 2009. Bacterial "Cell" phones: do cell phones carry potential pathogens. Online J. Health and Allied Sci., 8(1): 1-5.

Datta, P., Rani, H., Chander, J., Gupta, V. 2009. Bacterial contamination of mobile phones of health care workers. Indian J. Med. Microbiol., 27: 279-281.

Ducel, G., Fabry, J., Nicolle, L. 2002.Prevention of hospital-acquired infections. A practical guide, 2nd edition: World Health Organization, Department of Communicable Disease Surveillance and Response; pp 4-7.

Gunasekara, T.D., Kudavidanage, B.P., Peelawattage, M.K. et al. 2009. Bacterial contamination of anaesthetists 
hands, personal mobile phones and wrist watches used during theatre sessions. Sri Lankan J. Anaesthesiol., 17: 11-15.

Gurang, B., Bhati, P., Rani, U., Chawla, K., Mukhopodhyay, C., Barry, I. 2008. Do mobiles carry pathogens. Microcon.

Kabir OAkinyemi, Audu, D., Atapu, Olabisi, O., Adenota and Akitoye, O. Coker. 2009. The Potential role of mobile phones in the spread of bacterial infections. J. Infect. Dev. Countries, 3(8): 628-32.

Killic, I.H., Ozaslan, M., Karagoz, I.D., Zer, Y., Da-vatoglu, V. 2009. The microbial contamination of mo- bile phones used by healthcare staff. Pak. J. Biol. Sci.,12: 882-884.

Muktar, G., Daniel, A., Zelalem, A. 2014. Prevalence and Antimicrobial Susceptibility Pattern of Bacteria Isolated from Mobile Phones of Health Care Professionals Working in Gondar Town Health Centers, School of Biomedical and Laboratory Sciences, College of Medicine and Health Sciences, University of Gondar, P.O. Box 196, Gondar, Ethiopia. Academic Editors: B. G. L'opez-Valc'arcel and A. R. Mawson. Copyright (c) 2014 Muktar Gashaw et al.
Oguz, K., Esra, K., Mustafa, T. 2007. The role of mobile phones in the Spread of bacteria associated with nosocomial Infections. J. Infect Developing Countries, 1(1): 72-73.

Rawia, I.B., Hatem, I.B., Nabil, M.A. 2012. Mobile phones and Nosocomial infections. Int. J. Infect. Control, 8: i2 $1-5$.

Roth, R., Jenner, W. 1998. Microbial ecology of the skin. Annual Rev. Microbiol., 42: 441-64.

Sepehri, G., Talebizadeh, N., Mirzazadeh, A., Mir-Shekari, T.R., Sepehri, E. 2009. Bacterial contamination and resistance to commonly used antimicrobials of healthcare workers' mobile phones in teaching hospitals, Kerman, Iran. The American J. Appl. Sci., 6(5): 806-810.

Tambekar, D.H., Gulhane, P.B., Dahikar, S.G., Dud-hane, M.N. 2008. Nosocomial hazards of doctor's mo-bile phones in hospitals. J. Med. Sci., 8: 7376.

Ulger, F., Esen, S., Dilek, A., Yanik, K., Gunaydin, M. and Leblebicioglu, H. 2009. Are we aware how contaminated our mobile phones with nosocomial pathogens? Annals of Clin. Microbiol. Antimicrobials, 8: 1476-1487.

\section{How to cite this article:}

Ganapathy Shakthivel, P.C., G. Velvzhi, G. Sucilathangam, Revathy, C. 2017. Mobile Phones in Healthcare Setting: Potential Threat in Infection Control. Int.J.Curr.Microbiol.App.Sci. 6(3): 706-711. doi: https://doi.org/10.20546/ijcmas.2017.603.081 